\title{
Influence of glucose and stirring in the fermentation process in order to produce anti-Candida metabolites produced by Streptomyces sp.
}

\author{
Silvia Katrine Silva Escher ${ }^{1,2, *}$, José Jeosafá Vieira de Sousa Júnior ${ }^{2}$, Adrielle Leal Dias², \\ Elba Lúcia Cavalcanti de Amorim ${ }^{3}$, Janete Magalí de Araújo ${ }^{1}$
}

\begin{abstract}
${ }^{1}$ Microbiology Laboratory, UFOPA, Department of Antibiotics, UFPEDA, Program of Pharmaceutical. Sciences, Federal University of Pernambuco, UFPE, Recife, PE, Brazil, ${ }^{2}$ Microbiology Laboratory, UFOPA, Institute of Collective Health, UFOPA, Federal University of West Para, Santarém, PA, Brazil, ${ }^{3}$ Natural Products Laboratory, Federal University of Pernambuco, UFPE, Recife, PE, Brazil
\end{abstract}

\begin{abstract}
This study evaluated the influence of glucose and stirring in the fermentation process in order to produce anti-Candida metabolites produced by Streptomyces sp. MPO4 isolated from Amazon soil. The anti-Candida metabolites production was registered after $24 \mathrm{~h}$ of fermentation in stirred ISP2 medium, having antifungal inhibition halos between $12.3 \mathrm{~mm}$ and $25.3 \mathrm{~mm}$, yielding higher production of anti-Candida agents after $96 \mathrm{~h}$. Stirring was a determining factor for the production of anti-Candida secondary metabolites, since the absence of glucose reflected in the late production of the antifungal starting from Streptomyces sp.
\end{abstract}

Uniterms: Streptomyces sp./anti-Candida activity. anti-Candida metabolites/production. Fermentation.

Este estudo avaliou a influência da glicose e agitação no processo de fermentação para a produção de metabólitos anti-Candida produzidos por Streptomyces sp. MPO4 isolado do solo da Amazônia. A produção dos metabólitos anti-Candida foi registrada a partir de 24 h de fermentação sob agitação em meio ISP2, apresentando halos de inibição entre $12,3 \mathrm{~mm}$ e $25,3 \mathrm{~mm}$, obtendo-se maior produção do antifúngico em 96 h. A agitação foi um fator determinante para a produção de metabólitos secundários anti-Candida e a ausência de glicose refletiu na produção tardia do antifúngico a partir do Streptomyces sp.

Unitermos: Streptomyces sp./atividade anti-Candida. Metabólitos anti-Candida/produção. Fermentação.

\section{INTRODUCTION}

The bioactive compounds of microbial origin are produced by specific groups of bacteria and eukaryotic microorganisms such as Actinomycetes, Themyxobacteria, Pseudomonas and the Cyanobacteria and most of filamentous fungi.

Actinobacteria are Gram-positive filamentous bacteria group with high capacity to produce several secondary metabolites (Jørgensen et al., 2010; Karuppiah

*Correspondence: S. K. S. Escher. Departamento de Antibióticos. Programa de Ciências Farmacêuticas. Universidade Federal de Pernambuco. Av. Prof. Moraes Rego, 1235 - Cidade Universitária, Recife-CEP: 50670-901. E-mail: silvia.escher@ufopa.edu.br et al., 2013; Prakash et al., 2013; Kim, Yang, Yoon, 2015). They are usually isolated from soil consisting in about $30 \%$ of the microbial population (Goodfellow, Fiedler, 2010). In this group the Streptomyces genus are widely studied for its abilities to produce bioactive compounds used in the synthesis of about $70 \%$ of the antibiotics of choice in the treatment of microbial infections (Lacaz et al., 2002; Kim et al., 2012; Rashad et al., 2015) and 60\% are used in agriculture.

Actinomycetes may be exist in various habitats such as water, soil and plants, which are estimated for each gram of soil there are about $10^{6}-10^{9}$ Colony Forming Units (CFU) by actinomycetes. Its wide distribution is justified because these bacteria are not very demanding in terms of 
the substrate for growth, as they are described autotrophic genres, heterotrophic, chemotrophic or phototrophic (González et al., 2005).

In addition to antibiotics, metabolites related with the following activities: anti-inflammatory, antiparasitic, antiviral, antiprotozoal, immunomodulators, antitumor (Kim et al., 2012; Karuppiah et al., 2013; Manivasagan et al., 2014; Rashad et al., 2015) and vitamins (Shin et al., 2007; Arumugam et al., 2010) have also been isolated by fermentation processes of these bacteria (Manivasagan et al., 2014; Rashad et al., 2015).

This secondary metabolites is obtained by fermentative processes. The nature and concentration of nutrients in the medium such as carbon, nitrogen, phosphorus and minerals as well as the essential substances for biosynthetic pathway can promote the production of larger quantities of one or another compound inferring directly on its performance (Gupte, Kulkarni, 2002; Chen et al., 2012; El-Naggar et al., 2015).

Among the external factors with influence at the biosynthesis of secondary metabolites by microorganisms, the sources of carbon and nitrogen are highly relevant, since they are related to both substrate availability for the synthesis of metabolites as to the modulation of the enzymatic process and may activate and stabilize the enzymes involved in the process (Gupte, Kulkarni, 2002; El-Naggar et al., 2015).

Sugars such as glucose are routinely used as a carbon source for the growth and secondary metabolite production during fermentation. However, the production of some metabolites is suppressed by the inhibition of any enzyme involved in the process and consequently leads to activation of other metabolic pathways (El-Naggar et al., 2015; Sanchez, Quintero, Ochoa, 2015).

Both stirring or aeration favors the development of primary metabolism of aerobic microorganisms, especially during the multiplication stage, thus favoring the complete transformation of the sources of carbohydrates present in the fermentation medium (Muller et al., 2007).

The search for new bioactive compounds especially those with effective antimicrobial compounds against multiresitent microorganisms as Candida species can contribute to the control of this microorganism commonly associated with nosocomial infections. The increasing incidence of multidrug-resistant organisms is a major public health problem, especially Candida albicans, which although it is considered a commensal inhabitant of various parts of the body, particularly the gastrointestinal and genital tract, is associated with many cases of hospital infection, including the ability to promote primary infections in immunocompromised patients. (Avrella,
Goulart, 2008; Giolo, Svidzinski, 2010).

This study evaluated the influence of the glucose presence and stirring to produce compounds with antiCandida activity produced by Streptomyces sp. MPO-4 isolated from rhizosphere soil of Amazon.

\section{MATERIAL AND METHODS}

\section{Streptomyces sp. MPO4 strain}

The Streptomyces sp. MPO-4 used in this study was obtained from the collection of the culture of Microbiology Laboratory of the Federal University of West Para. The lineage is a rhizosphere actinomycete from the tree Aniba parviflora syn $A$. fragans (Macacaporanga) and was isolated from the transition area between dense forest and savanna in the Amazon rainforest (2028'S and 54049'W) in Santarém - PA (Figure 1).

The Streptomyces sp. MPO4 was isolated on Agar Yeast Arginine medium (AYA: $0.3 \mathrm{~g}$ L-arginine, $1 \mathrm{~g}$ glucose, $1 \mathrm{~g}$ glycerol, $0.3 \mathrm{~g} \mathrm{~K}_{2} \mathrm{HPO}_{4}, 0.2 \mathrm{~g} \mathrm{MgSO}_{4} .7 \mathrm{H}_{2} \mathrm{O}$, $0.3 \mathrm{~g} \mathrm{NaCl}, 1 \mathrm{~g}$ yeast extract, $1 \mathrm{~mL}$ Salt Solution $[0.1 \mathrm{~g}$ FeSO4.7 $\mathrm{H}_{2} \mathrm{O}, 0.1 \mathrm{~g} \mathrm{MnCl}_{2} .4 \mathrm{H}_{2} \mathrm{O}, 0.1 \mathrm{~g} \mathrm{ZnSO}_{4} .7 \mathrm{H}_{2} \mathrm{O}$, $100 \mathrm{~mL}$ distilled water, $\mathrm{pH}$ 7.0-7.4], $17 \mathrm{~g}$ agar, $1000 \mathrm{~mL}$ distilled water, pH 6.4) (Nonomura, Ohara, 1969) plus nystatin $(100 \mu \mathrm{g} / \mathrm{mL})$ at $30^{\circ} \mathrm{C}$ for 14 days from the serial dilution $\left(10^{-3}, 10^{-4}\right.$ e $\left.10^{-5} \mathrm{CFU} / \mathrm{mL}\right)$ of $10 \mathrm{~g}$ soil adhered to the plant root in $90 \mathrm{~mL}$ of phosphate buffer. The morphological identification was made through evaluation of cultural characters and micromorphology (Williams, Sharpe, Holt, 1989).

\section{Anti-Candida activity}

Streptomyces sp. MPO-4 was grown on ISP2 medium (International Streptomyces Project: $4 \mathrm{~g}$ yeast extract, $10 \mathrm{~g}$ malt extract, $4 \mathrm{~g}$ glucose, $15 \mathrm{~g}$ agar, 1000 $\mathrm{mL}$ distilled water, $\mathrm{pH}$ 7.2) (Shirling, Gottlieb, 1966) in Petri dish $(60 \times 15 \mathrm{~mm})$ incubated at $30^{\circ} \mathrm{C}$ for 168 hours for sporulation and colonization of the entire surface of the culture medium.

The evaluation of the anti-Candida activity of Streptomyces sp. MPO4 was initially performed by the method of agar block (Ichikawa et al., 1971) against Candida albicans (UFPEDA1007) starting from agar blocks of $6 \mathrm{~mm}$ in diameter containing Streptomyces sp. MPO4 cultures grown for 14 days at $30{ }^{\circ} \mathrm{C}$ in dish plates containing Sabouraud Glucose Agar (SDA) (20 g glucose, 5 g pepitic digest of animal tissue, $5 \mathrm{~g}$ pancreatic digest of casein, $15 \mathrm{~g}$ agar, $1000 \mathrm{~mL}$ distilled water, $\mathrm{pH}$ 5.6) previously inoculated with the Candida suspension 


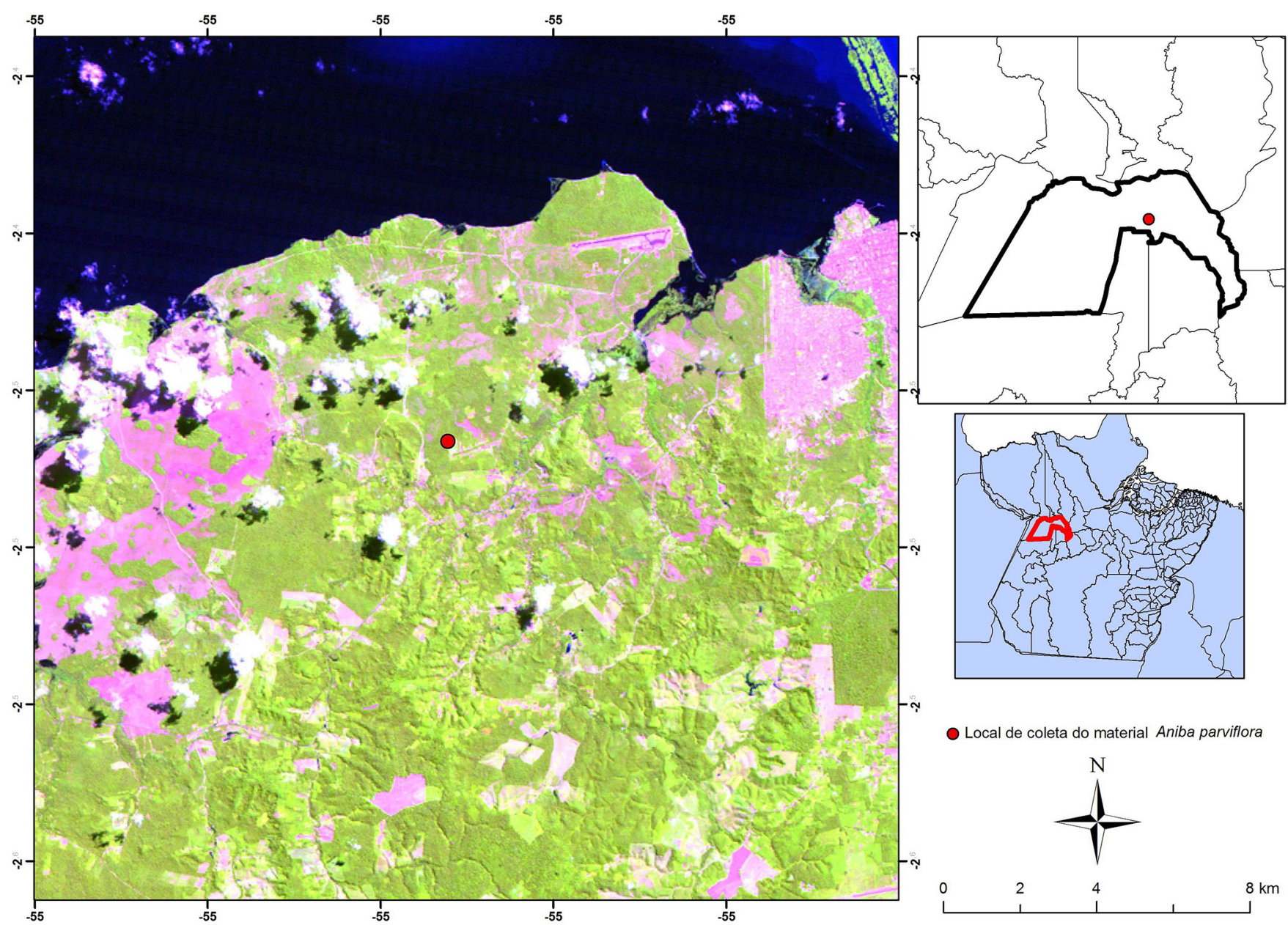

FIGURE 1 - Map of geographic coordinates of the soil sampling point rhizosphere of Aniba parviflora syn A. fragans (Macacaporanga) (Latitude 2028 '01.28 “'S Longitude 540 49’ 45.32).

adjusted to $0.5 \mathrm{McF}$ arland. The plates were maintained at $30{ }^{\circ} \mathrm{C}$ and for $48 \mathrm{~h}$ to observe the inhibition halo.

It was adopted a completely randomized design with 4 replications. Data were subjected to analysis of variance and means compared by Tukey test with $5 \%$ of probability.

Intensity of the inhibitory activity was classified according to Sahin and Ugur (2003), and the size of the inhibition zone divided into four different groups: group ability-zone of inhibition less than $10 \mathrm{~mm}$; slightly active group-inhibition zone between 11 and $20 \mathrm{~mm}$; moderately active group-inhibition zone between $21.2 \mathrm{~mm}$ and $30 \mathrm{~mm}$; and highly active group, whose zone of inhibition is greater than $31 \mathrm{~mm}$.

\section{Fermentation}

After anti-Candida's activity screening, was carried submerged fermentation in $250 \mathrm{~mL}$ erlenmeyer flask using the ISP2 medium from $50 \mathrm{~mL}$ of the pre-inoculum kept under stirring of $180 \mathrm{rpm}$ (Magnetic stirrer Fisatom ${ }^{\circledR}$
Mode 1751) for $48 \mathrm{~h}$ at room temperature (Braga et al., 1967). An aliquot of $10 \%$ of the pre-inoculum was used for fermentation in ISP2 medium with $4 \%$ dextrose and ISP2 modified by removal of dextrose. The fermentation occurred both under agitation of $180 \mathrm{rpm}$ for $168 \mathrm{~h}$ and without stirring. The anti-Candida activity, temperature, $\mathrm{pH}$ and weight of the biomass were monitored every $24 \mathrm{~h}$ (Braga et al., 1967).

To evaluate the anti-Candida activity to every $24 \mathrm{~h}$ the fermented liquid was centrifuged ( $927 \mathrm{~g}, 10$ minutes) to precipitate the biomass and $100 \mu \mathrm{L}$ of the supernatant were used on the test by the diffusion method in wells (Thakur et al., 2009) in Petri dishes containing Sabouraud Glucose Agar (SDA) previously inoculated with the Candida albicans suspension. The plates were incubated at $30{ }^{\circ} \mathrm{C}$ for $48 \mathrm{~h}$ and the antifungal activity was detected by the presence of zones of inhibition in millimeters. It was adopted a completely randomized design with 4 replications. Data were subjected to analysis of variance and means compared by Tukey test at 5\% probability. 
TABLE I - Mean values of halos of inhibition of Candida albicans growth compared to the different liquid fermented

\begin{tabular}{lcccc}
\hline Fermentation time & $\begin{array}{c}\text { ISP2 } \\
\text { With stirring }\end{array}$ & $\begin{array}{c}\text { ISP2 } \\
\text { Without stirring }\end{array}$ & $\begin{array}{c}\text { ISP2 Modified } \\
\text { With stirring }\end{array}$ & $\begin{array}{c}\text { ISP2 Modified } \\
\text { Without stirring }\end{array}$ \\
\hline $24 \mathrm{~h}$ & $12.3 \pm 0.58^{\mathrm{aF}}$ & - & - & - \\
$48 \mathrm{~h}$ & $15.3 \pm 0.58^{\mathrm{aE}}$ & - & - & - \\
$72 \mathrm{~h}$ & $21.3 \pm 0.58^{\mathrm{aC}}$ & - & - & - \\
$96 \mathrm{~h}$ & $25.3 \pm 0.58^{\mathrm{aA}}$ & - & $24.3 \pm 0.58^{\mathrm{aA}}$ & - \\
$120 \mathrm{~h}$ & $24 \pm 1.73^{\mathrm{aAB}}$ & - & $23 \pm 1^{\mathrm{aA}}$ & - \\
$144 \mathrm{~h}$ & $23 \pm 1^{\mathrm{aB}}$ & - & $19.3 \pm 0.58^{\mathrm{bB}}$ & - \\
$168 \mathrm{~h}$ & $19.3 \pm 0.58^{\mathrm{aD}}$ & - & $13.3 \pm 1^{\mathrm{bC}}$ & - \\
\hline
\end{tabular}

Same letters are not statistically different by Tukey test $(\mathrm{p}<0.05)$

The quantification of wet biomass was done by centrifuging the fermented liquid ( $927 \mathrm{~g}, 20 \mathrm{~min}$ ) in falcon cones with their weight previously measured. Subsequently, it was removed the supernatant and it was measured the weight of biomass that remained at the falcon cone.

\section{Obtaining metabolites}

The fermented liquid was filtered through cellulose acetate $0.22 \mu \mathrm{m}$ porosity filter and the filtrate was subjected to extraction of secondary metabolites using ethyl acetate for 3 steps at a ratio $(2: 1)$ under mechanical stirring for $1 \mathrm{~h}$ at $180 \mathrm{rpm}$. The organic phase was concentrated on a rotary evaporator to obtain the crude extract.

\section{RESULTS}

The anti-Candida activity of fermented liquid in ISP2 medium varied according to fermentation time, showing growth inhibition zones of between $12.3 \mathrm{~mm}$ and $25.3 \mathrm{~mm}$. These activities are therefore classified as moderately active and slightly active, respectively (Table I).

Inhibition zones were registered only in the metabolic liquid after a $24 \mathrm{~h}$ fermentation process. In $96 \mathrm{~h}$, the production of anti-Candida metabolites was increased. The zones of inhibition for Candida albicans can be seen in Figure 2.

Stirring was a determining factor for the production of antifungal secondary metabolites, but was not significant for the production of biomass (Figure 3 ).

Carbon source was an important factor in the production of anti-Candida metabolites, and the presence of glucose optimizes the production of metabolites in shorter fermentation, with production of antifungal metabolites in the fermentation liquid in ISP2 modified stirring from $96 \mathrm{~h}$ fermentation. The carbon source influenced positively also in the production of biomass.

\section{DISCUSSION}

The ISP2 medium proved to be a good alternative for the generation of bioactive metabolites with antifungal activity by submerged fermentation (Cunha et al., 2009). Analyzing the fermentation process in different culture media of endophytic strain Streptomyces sp. EBR-49 UFPEDA isolated from plant roots Conyza bonariensis (L.), it was observed that the largest zones of inhibition were against Bacillus subtilis ATCC 6633 in ISP2 medium, concluding that this is the best medium for the production of bioactive compound for that lineage.

Also, it was evaluated the production of antimicrobial metabolites testing different culture medium for fermentation which achieved better inhibition halo from the fermented liquid $72 \mathrm{~h}$ at ISP2 with (4\%) carbon source (glucose) and recorded growth inhibition zones $24.5 \mathrm{~mm}$ at $72 \mathrm{~h}$ of fermentation.

Carbon source and the aeration development of primary metabolism resulting in increased biomass and interferes with antibiotic production by the suppression of the biosynthetic enzymes (Muller et al., 2007; Demain, Sanchez, 2009). In this study the carbon source interferes on late production of anti-Candida metabolites and stirring was a determinate factor of antibiotic metabolites production.

Therefore, the selection of culture media is essential during the process of production of antibiotics by microorganisms. Since, microbial growth this not directly related to the production of antimicrobial metabolites. Thus a microorganism can grow without producing metabolites with this property, thus resulting in a significant amount of biomass and allows yield of bioactive metabolites. Thakur et al. (2009) observed during fermentation of Streptomyces sp. 201 that the antimicrobial activity of the fermented liquid was not related to biomass amount.

Salamoni (2009) described the antimicrobial activity obtained from the fermentation of 25 species of 


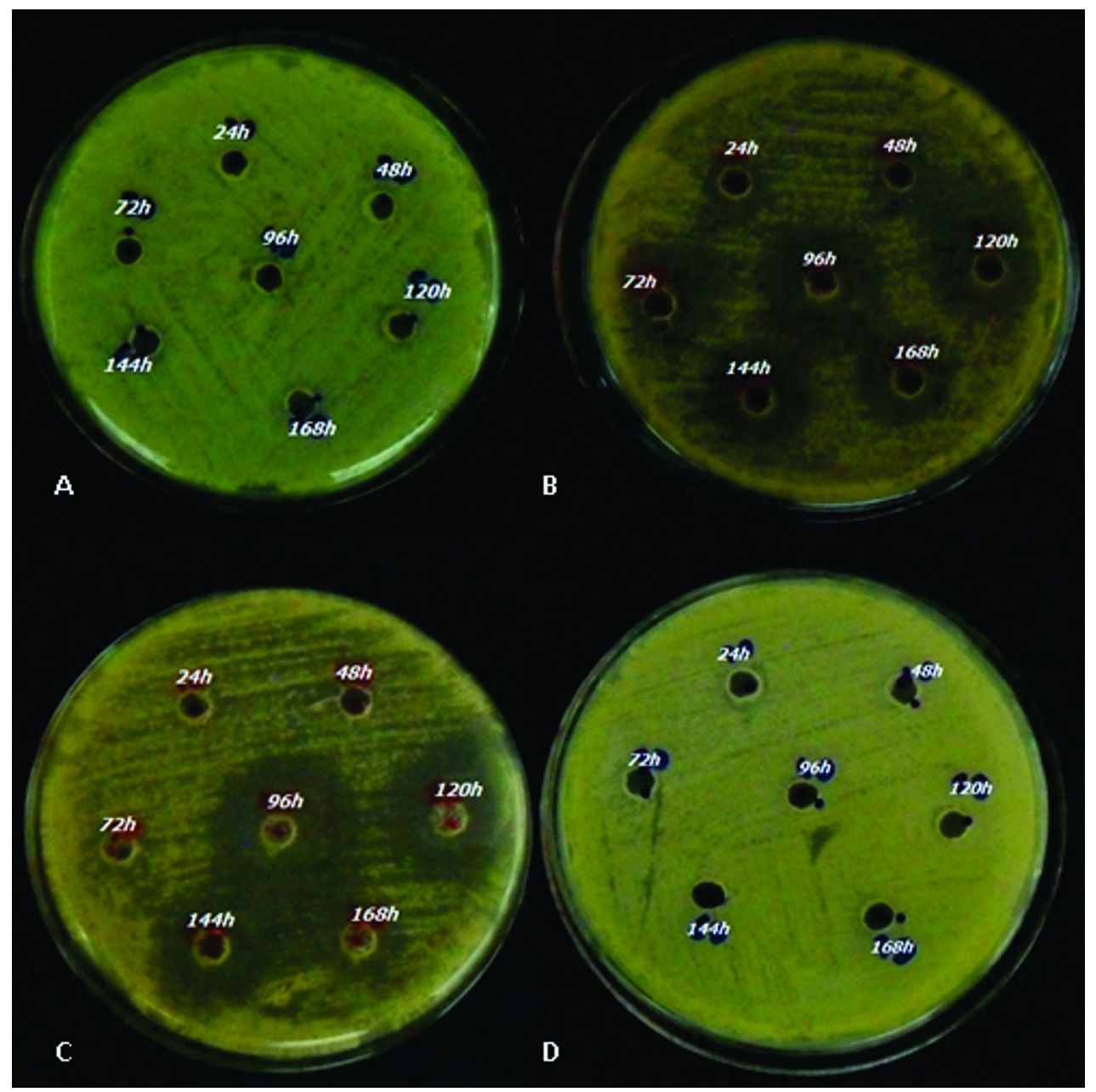

FIGURE 2 - Anti-Candida activity of fermented liquid Streptomyces sp. MPO-4 against Candida albicans. A) Fermented liquid ISP2 without stirring; B) Fermented liquid ISP2 with stirring; C) Fermented liquid ISP2 modified with stirring; D) Fermented liquid ISP2 modified without stirring.

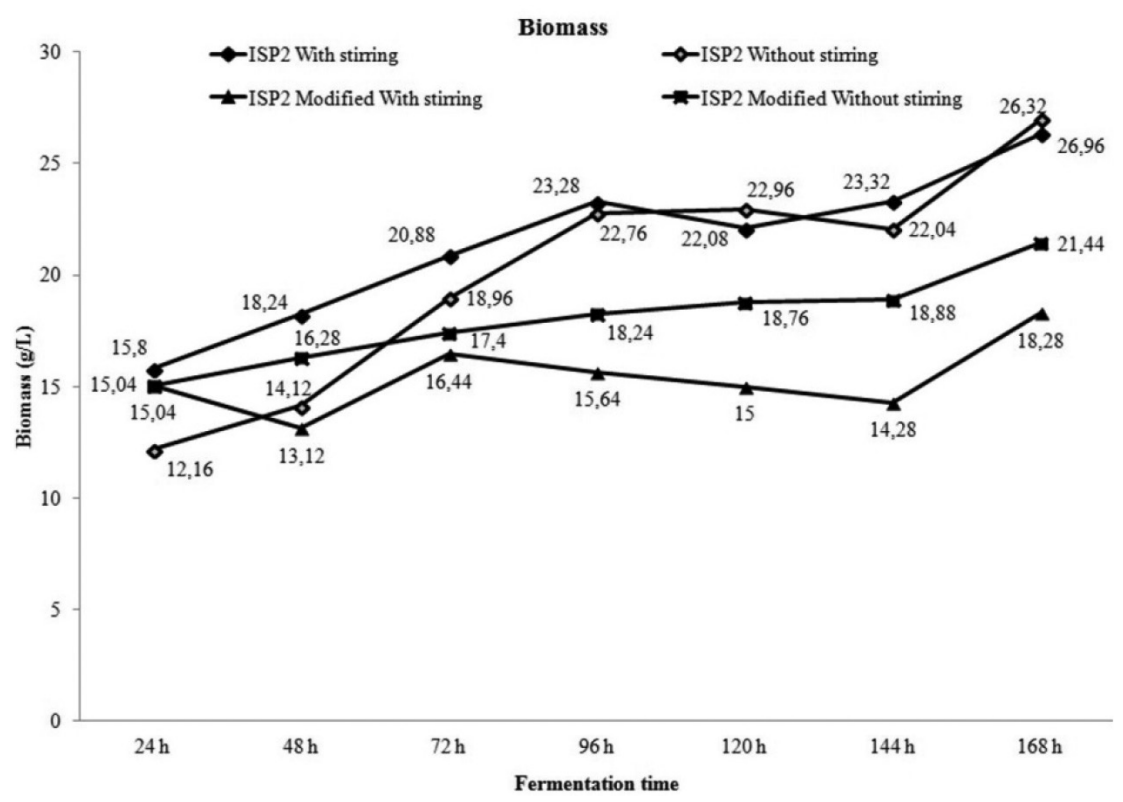

FIGURE 3 - Growth of biomass $v s$ time in different fermentation conditions. 
actinomycetes of the genus Streptomyces using mineral medium of casein and starch, and ISP2 medium, where $80 \%$ of the isolates were able to inhibit at least one of the tested bacteria. In another study, Salamoni, Van der Sand and Germani (2012) gave better yield of antimicrobial metabolites by the fermentation of Streptomyces sp.1S on ISP 2 medium at $28^{\circ} \mathrm{C}$ by the $24 \mathrm{~h}$ of fermentation, by being active against Gram-positive and Gram-negative bacteria, and even yeasts such as Candida albicans and filamentosus fungi.

\section{CONCLUSION}

Streptomyces sp. MPO-4 isolated from the rhizosphere soil of Aniba parviflora Syn A. fragans (Macacaporanga) produces anti-Candida metabolites with increased activity in fermentation in ISP2 medium with glucose and stirring, having inhibition halos between 12.3 $\mathrm{mm}$ and $25.3 \mathrm{~mm}$, yielding higher production of antifungal agents after $96 \mathrm{~h}$. Stirring was a determining factor for the production of anti-Candida secondary metabolites, since the absence of glucose reflected in the late production of the anti-Candida metabolites.

Bioprospecting of microorganisms with biotechnological potential has enabled the use of bioactive compounds in several areas of knowledge, and the isolation of actinomycetes present in differentiated soil such as the Amazon as well as the elucidation of compounds bioactive, represent the primary goal for this research group, presenting this way, as a possibility of local scientific development generating immediate impact for the pharmaceutical, food industry, environmental and cosmetology, thereby resulting in social and economic development of the Amazon.

\section{ACKNOWLEDGEMENTS}

Conselho Nacional de Desenvolvimento Científico e Tecnológico (CNPq) and Coordenação de Aperfeiçoamento de Pessoal de Nível Superior (CAPES) for the financial support.

\section{REFERENCES}

ARUMUGAM, M.; MITRA, A.; JA ISANKAR, P.; DASGUPTA, S.; SEN, T.; GACHHUI, R.; MUKHOPADHYAY, U. K.; MUKHERJEE, J. Isolation of an unusual metabolite 2-allyloxyphenol from a marine actinobacterium, its biological activities and applications. Appl. Microbiol. Biotechnol., v.86, n.1, p.109-117, Mar 2010.
AVRELLA, D.; GOULART, L. S. G. Isolamento de Candida spp. da mucosa oral de pacientes submetidos ao tratamento quimioterápico. Rev. Bras. Anal. Clin., v.40, n.3, p.205-207, 2008.

BRAGA, A. S.; GABRIEL, S. J.; CARRAZZONI, E. P.; GOTTLIEB O. R.; Lyra, F. D. A. Ciclamicina e ciclacidina. An. Acad. Bras. Ciênc., v.39, p. 253-254, 1967.

CHEN, Y.; NTAI, I.; JU, K. S.; UNGER, M.; ZAMDBORG, L.; ROBINSON, S. J.; DOROGHAZI, J. R.; LABEDA, D. P.; METCALF, W. W.; KELLEHER, N. L. A proteomic survey of nonribosomal peptide and polyketide biosynthesis in actinobacteria. J. Proteome Res., v.11, n.1, p.85-94, Jan 1,2012 .

CUNHA, I. G. B. da; PEIXOTO SOBRINHO, T. J. da S.; SILVA, R. E. A. da; AMORIM, E. L. C. de; ARAÚJO, J. M. de. Influência do meio de cultura na produção de metabólitos bioativos do endófito Streptomyces sp. EBR49-A UFPEDA. Rev. Bras. Farm., v.90, n.2, p.120-123, 2009.

DEMAIN, A. L.; SANCHEZ, S. Microbial drug discovery: 80 years of progress. J. Antibiot. (Tokyo), v.62, n.1, p.5-16, 2009.

EL-NAGGAR, N-A.; MOAWAD, H.; EL-SHWEIHY, N. M.; EL-EWASY, S. M. Optimization of culture conditions for production of the anti-leukemic glutaminase free L-asparaginase by newly isolated Streptomyces olivaceus NEAE-119 using response surface methodology. Biomed. Res. Int., v.2015, p.627031, 2015.

GIOLO, M. P.; SVIDZINSKI, T. I. E. Phisiopathogenesis, epidemiology and laboratory diagnosis of candidemia. $J$. Bras. Patol. Med. Lab., v.46, n.3, p.225-234, 2010.

GONZÁlEZ, I.; AYUSO-SACIDO, A.; ANDERSON, A.; GENILLOUD, O. Actinomycetes isolated from lichens: evaluation of their diversity and detection of biosynthetic gene sequences. FEMS microbiology ecology, v.54, n.3, p.401-415, 2005.

GOODFELLOW, M.; FIEDLER, H. P. A guide to successful bioprospecting: informed by actinobacterial systematics. $A$. Van Leeuw. J. Microb., v.98, n.2, p.119-142, 2010. 
GUPTE, M. D.; KULKARNI, P. R. A study of antifungal antibiotic production by Streptomyces chattanoogensis MTCC 3423 using full factorial design. Lett. Appl. Microbiol., v.35, n.1, p.22-26, 2002.

ICHIKAWA, T.; DATE, M.; ISHIKURA, T.; OZAKI, A. Improvement of kasugamycin-producing strain by the agar piece method and the prototroph method. Folia Microbiol. (Praha), v.16, n.3, p.218-224, 1971.

JØRGENSEN, H.; DEGNES, K. F.; DIKIY, A.; FJAERVIK, E.; KLINKENBERG, G.; ZOTCHEV, S. B. Insights into the evolution of macrolactam biosynthesis through cloning and comparative analysis of the biosynthetic gene cluster for a novel macrocyclic lactam, ML-449. Appl. Environ. Microbiol., v.76, n.1, p.283-293, Jan 2010.

KARUPPIAH, V.; AARTHI, C.; SIVAKUMAR, K.; KANNAN, L. Statistical optimization and anticancer activity of a red pigment isolated from Streptomyces sp. PM4. Asian Pac. J. Trop. Biomed., v.3, n.8, p.650-656, Aug 2013.

KIM, B. Y.; ZUCCHI, T. D.; FIEDLER, H. P.; GOODFELLOW, M. Streptomyces cocklensis sp. nov., a dioxamycinproducing actinomycete. Int. J. Syst. Evol. Microbiol., v.62, pt.2, p.279-283, Feb 2012.

KIM, E. J.; YANG, I.; YOON, Y. J. Developing Streptomyces venezuelae as a cell factory for the production of small molecules used in drug discovery. Arch. Pharm. Res., v. 38, n.9, p.1606-1616, Jul 28, 2015.

LACAZ, C. S.; PORTO, E.; MARTINS, J. E. C.; HEINSVACCARI, E.M.; MELO, N. T. de. Tratado de Micologia médica. 9. ed. São Paulo: Sarvier, 2002. 1104p.

MANIVASAGAN, P.; VENKATESAN, J.; SIVAKUMAR, K.; KIM, S. K. Pharmaceutically active secondary metabolites of marine actinobacteria. Microbiol. Res., v.169, n.4, p.262$278,2014$.

MUller, J. L.; PROTTI, K. L.; MACHADO, M. da S.; LACERDA, L. L. V. de; BRESOLIN, T. M. B.; PODLECH, P. S. Comparação do crescimento de Saccharomyces boulardii em fermentador por batelada tipo Air-lift e shaker. Ciênc. Tecnol. Aliment., v.27, n.4, p.688-693, 2007.
NONOMURA, H.; OHARA, Y. Distribution of soil actinomycetes. VI. A culture method effective for both preferential isolation and enumeration of Microbispora and Streptosporangium strains in soil. J. Ferment. Technol., v.47, p.463-469, 1969.

PRAKASH, D.; NAWANI, N.; PRAKASH, M.; BODAS, M.; MANDAL, A.; KHETMALAS, M.; KAPADNIS, B. Actinomycetes: a repertory of green catalysts with a potential revenue resource. Biomed. Res. Int., v.2013, 8p., ID.264020, 2013.

RASHAD, F. M.; FATHY, H. M.; EL-ZAYAT, A. S.; ELGHONAIMY, A. M. Isolation and characterization of multifunctional Streptomyces species with antimicrobial, nematicidal and phytohormone activities from marine environments in Egypt. Microbiol. Res., v.175, p.34-47, Jun 2015.

SAHIN, N.; UGUR, A. Investigation of the antimicrobial activity of some Streptomyces isolates. Turk. J. Biolog., v.27, p.79-82, 2003.

SALAMONI, S. P. Avaliação da atividade antimicrobiana de isolados de Streptomyces e estudo de produção de moléculas bioativas. Porto Alegre, 2009. 141 p. Tese de doutorado - Instituto de Ciências Básicas da Saúde Universidade Federal do Rio Grande do Sul.

SALAMONI, S. P.; VAN DER SAND, S. T.; GERMANI, J. C. Estudo de produção de compostos com atividade antimicrobiana produzidos por Streptomyces sp. $1 \mathrm{~S}$. Evidência: Ciência e Biotecnologia, v.12, n.2, p.175-186, 2012.

SANCHEZ, C.; QUINTERO, J. C.; OCHOA, S. Flux balance analysis in the production of clavulanic acid by Streptomyces clavuligerus. Biotechnol. Prog., v.31, n.5, p.1226-1236, Jul 14, 2015.

SHIN, H. J.; JEONG, H. S.; LEE, H. S.; PARK, S. K.; KIM, H. M.; KWON, H. J. Isolation and structure determination of streptochlorin, an antiproliferative agent from a marine-derived Streptomyces sp. 04DH110. J. Microbiol. Biotechnol., v.17, n.8, p.1403-1406, Aug 2007.

SHIRLING, E. B.; GOTTLIEB, D. Methods for characterization of Streptomyces species. Int. J. Syst. Evol. Microbiol., v.16, n.3, p.313-340, 1966, 
THAKUR, D.; BORA, T. C.; BORDOLOI, G. N.; MAZUMDAR, $\mathrm{S}$. Influence of nutrition and culturing conditions for optimum growth and antimicrobial metabolite production by Streptomyces sp. 201. J. Mycol. Med, v.19, n.3, p.161167, 2009.
WILLIAMS, S.; SHARPE, M.; HOLT, J. Bergey's manual of systematic bacteriology. V 4. Baltimore: Williams and Wilkins, 1989.

Received for publication on $23^{\text {th }}$ January 2015 Accepted for publication on $12^{\text {th }}$ April 2016 